\title{
A redescription of Arostrilepis horrida (Linstow, 1901) and descriptions of two new species from Palaearctic microtine rodents, Arostrilepis macrocirrosa sp.n. and $A$. tenuicirrosa sp.n. (Cestoda: Hymenolepididae)
}

\author{
Arseny A. Makarikov ${ }^{1,2}$, Vladimir D. Gulyaev ${ }^{2}$ and Vytautas L. Kontrimavichus ${ }^{1}$ \\ ${ }^{1}$ Institute of Ecology of Nature Research Centre, Akademijos 2, Vilnius 08412, Lithuania; \\ ${ }^{2}$ Institute of Systematics and Ecology of Animals, Siberian Branch, Russian Academy of Sciences, Frunze St. 11, 630091 \\ Novosibirsk, Russia
}

\begin{abstract}
The type species of the cestode genus Arostrilepis Mas-Coma et Tenora, 1997, Arostrilepis horrida (Linstow, 1901), is redescribed on the basis of the syntype material from the brown rat (Rattus norvegicus) deposited in the collection of the Museum für Naturkunde, Berlin. Arostrilepis horrida (sensu lato), reported from a wide range of rodents throughout the Holarctic Region, is shown to be a species complex. The proposed host range and geographical distribution of $A$. horrida (sensu stricto) are limited to the data reported in the original description. The previously proposed synonymy of $A$. horrida is examined and the following species are excluded from the list of its synonyms: Hymenolepis procera Janicki, 1904, H. arvicolina Cholodkowsky, 1913, H. sciurina Cholodkowsky, 1913 and H. mathevossianae Akhumyan, 1946; these are considered species inquirendae. Specimens previously identified as $A$. horrida from voles from the Asian part of Russia are revised and newly collected materials are worked out. Two new species, A. macrocirrosa sp. n. and A. tenuicirrosa sp. n., are described. The main differentiating characters used to distinguish Arostrilepis spp. are the form and size of cirrus and its armature as well as the type of arrangement for the testes. The new species can also be distinguished from one another on the basis of sequences of the ITS2 rRNA gene. The generic diagnosis of Arostrilepis is emended. Hymenolepis neurotrichi Rausch, 1962, which had been placed in Arostrilepis by Mas-Coma and Tenora (1997), does not correspond to the generic diagnosis and is considered a species incertae sedis.
\end{abstract}

Keywords: Cestoda, Hymenolepididae, Arostrilepis horrida, redescription, Arostrilepis macrocirrosa, Arostrilepis tenuicirrosa, new species, morphology, microtine rodents

The original description of Arostrilepis horrida (Linstow, 1901) [syn.: Taenia horrida Linstow, 1901; Hymenolepis horrida (Linstow, 1901)] from the brown rat Rattus norvegicus (Berkenhout) from Germany (Linstow 1901) is inadequate. As a consequence, nearly all hymenolepidid cestodes from rodents possessing an unarmed scolex and lacking a vestigial rostellar apparatus have been identified as $A$. horrida (see Baer 1932, Schiller 1952, Voge 1952, Spassky 1954, Żarnowski 1955, Rybicka 1959, Surkov and Nadtochii 1970, Murai and Tenora 1973, Egorova and Nadtochii 1975, Genov 1984, Fedorov 1986, Kontrimavichus and Smirnova 1991, Mas-Coma and Tenora 1997, Asakawa et al. 2002). Thus, the published data create the impression that $A$. horrida has a Holarctic distribution and occurs in a diverse assemblage of rodent definitive hosts (i.e., Sciuridae, Myoxidae, Zapodidae, Cricetidae, Gerbillinae and Muridae) (Ryzhikov et al. 1978, Mas-Coma et al. 1980). It has not been found in Muridae, including the designated type host, since its original description. Furthermore, A. horrida (s. 1.) holds a central role in this group of tapeworms as it was designated as the type species of the genus Arostrilepis Mas-Coma et Tenora, 1997 (see Mas-Coma and Tenora 1997).

Only recently, two additional species were reported in this genus. These were A. beringiensis (Kontrimavichus et Smirnova, 1991) Gulyaev et Chechulin, 1997 from lemmings in Chukotka (Kontrimavichus and Smirnova 1991) and A. microtis Gulyaev et Chechulin, 1997 from voles of the genus Microtus Schrank from the Altai Mts. and Western Siberia (Gulyaev and Chechulin 1997). The lack of clear species limits and a contemporary redescription of the type series of $A$. horrida hinder further studies of species diversity in this group.

Syntype material of $A$. horrida is preserved in the Helminthological Collection of the Museum für Naturkunde in Berlin, Germany. This allowed us to prepare a rede-

Address for correspondence: A. Makarikov, Institute of Ecology of Nature Research Centre, Akademijos 2, Vilnius 08412, Lithuania. Phone: +370 527292 69; Fax: +370 527293 52; E-mail: makarikov@mail.ru 
scription and to initiate extensive studies to resolve species diversity within the Arostrilepis-complex. During a survey of the helminth fauna of red-backed voles (Myodes Pallas) in the Sakhalin Region (Sakhalin and Kunashir Islands), we found two other species belonging to Arostrilepis. Further, examination of specimens from the collections of the Institute of Systematics and Ecology of Animals, Novosibirsk (ISEZH), indicated that hymenolepidid cestodes from microtine rodents, which had been identified as $A$. horrida and originated from the Altai Mts., Siberia and the Russian Far East, also belonged to these two new species. These species are specific parasites of red-backed voles and can be easily distinguished from the type species and from congeners, A. microtis and $A$. beringiensis, by the size and shape of suckers, the size and armature of the cirri and the topography of the internal organs. In this article, we provide a redescription of the type species of the genus Arostrilepis based on syntype specimens and describe two new species of the same genus from Myodes spp.

\section{MATERIALS AND METHODS}

Cestodes from rodents were collected during June 2005 in the Poronayskiy Reserve, near the town of Poronaysk on Sakhalin Island, and during July 2006 in the Kurilskiy Reserve located on Kunashir Island. Three species of Myodes were sampled: M. rutilus (Pallas) (17 specimens), M. rufocanus (Sundevall) (37 specimens) and $M$. sikotanensis (Tokuda) (9 specimens). Another series of cestodes from M. glareolus (Schreber) was collected from Yarkovskiy Rayon, Tyumenskaya Oblast' from July to August 2007.

Host specimens were dissected immediately after their death. Cestodes were isolated, washed and relaxed in water; they were then fixed in $70 \%$ ethanol. They were stained with Ehrlich's haematoxylin, differentiated in a $3 \%$ aqueous solution of ferricammonium sulphate 12-hydrate, dehydrated in an ethanol series, cleared in clove oil and mounted in Canada balsam. Some specimens were mounted in Berlese's medium to facilitate the examination of their copulatory apparatus. Tissue from 13 cestode individuals was stored in $70-96 \%$ ethanol for DNA analysis (Haukisalmi et al. 2007).

The type specimens of the two new species were deposited into the collections of the Zoological Museum at the Institute of Systematics and Ecology of Animals, Novosibirsk (ISEZH), the Natural History Museum, Geneva, Switzerland (MHNG) and the Institute of Parasitology, Academy of Sciences of the Czech Republic, České Budějovice, Czech Republic (IPCAS).

The following type materials from previously described species were studied: a syntype of A. horrida, No. 3640-Q, Museum für Naturkunde, Berlin, Germany, loaned by Dr. Birger Neuhaus; A. beringiensis, No. 646 (holotype), No. 647 (paratype), Centre of Parasitology of the A.N. Severtsov Institute of Ecology and Evolution of the Russian Academy of Sciences, Moscow, Russia; A. microtis; No. C 751 (holotype), No. C 752761 (paratypes), Zoological Museum of ISEZH, Novosibirsk, Russia; A. neurotrichi No. 59813 (holotype), US National Parasite Collection, ARS, USDA, Beltsville, MD, USA loaned by Dr. Eric P. Hoberg.
The collections of the Zoological Museum of ISEZH, Novosibirsk included more than 650 slides of cestodes of the genus Arostrilepis from microtine rodents from the Altai Mts., Siberia and the Russian Far East. They were also examined in the course of the present study.

Measurements are given in micrometres except where otherwise stated. Metrical data for the holotypes are followed by those for paratypes in parentheses.

Tissue samples (c. 1.5-2 mm long) from cestodes were used for total DNA extraction. They were dried, and then placed in SET-buffer. The DNA was extracted using a standard phenolchloroform protocol as described by Vainio et al. (1998) and Sambrook and Russell (2002). A fragment of the ITS2 region of the rRNA was amplified using the following primers: Proteo $1 \mathrm{~F}$ (5'-CGG TGG ATC ACT CGG CTC-3') and Proteo 2 R (5'-TCC TCC GCT TAT TGA TAT GC-3') (Škeříková et al. 2001, Bean et al. 2007). The cycling profile consisted of an initial denaturation for $2: 30 \mathrm{~min}$ at $95^{\circ} \mathrm{C}, 35$ cycles of $45 \mathrm{~s}$ at $95^{\circ} \mathrm{C}, 45 \mathrm{~s}$ at $53^{\circ} \mathrm{C}$, $1 \mathrm{~min}$ at $72^{\circ} \mathrm{C}$ and a final extension at $72^{\circ} \mathrm{C}$ for $10 \mathrm{~min}$. The amplification was evaluated by running $3 \mu \mathrm{l}$ of the final PCR product on a $2 \%$ agarose gel. Sequencing (from both sides) was carried out by Macrogen Inc. (Geumchun-gu Seoul 153-781, Korea) using the same primers.

Sequences were assembled using Sequencher 4.7 (Gene Codes Corporation); they were edited by visual inspection. Consensus sequences were aligned in Clustal W (Thompson et al. 1994) using BioEdit (Hall 2005). We used the MEGA software package (Version 4) to construct a neighbour-joining (NJ) tree with a Kimura 2-parameter distance substitution model (Kumar et al. 2004). For construction of the phylogenetic tree, we used 13 newly obtained sequences (deposited in GenBank). Two sequences of Hymenolepis diminuta (Rudolphi, 1819) and Hymenolepis (s. 1.) nana (Siebold, 1852) were downloaded from GenBank (Okamoto et al. 1997) and were used as an outgroup. Bootstrap values were counted using MEGA as the percentage of 1,000 replicates.

\section{RESULTS}

Arostrilepis horrida (Linstow, 1901) Mas-Coma et Tenora, 1997

Fig. 1

Syns.: Taenia horrida Linstow, 1901; Hymenolepis horrida (Linstow, 1901).

Redescription. Total length and number of proglottides cannot be described. Maximum width at posterior part of strobila, 1.87-1.93 mm. Strobila flat, proglottides craspedote. Scolex slightly compressed dorso-ventrally, 270-300 wide, clearly wider than neck. Suckers unarmed, with ovoid outlines, 133-145 × 128-134, prominent, with thin walls (Fig. 1A). Rhynchus and rostellar apparatus absent. Neck relatively long and narrow, 16-17 wide.

Development of proglottides gradual, protandrous. Strobilar part containing juvenile proglottides without external segmentation; proglottides become externally distinct at level of premature part of strobila. Genital pores unilateral, dextral.

Mature proglottides transversely elongate, trapezoid, 90-130 × 1840-1930 (Fig. 1C, D). Testes relatively large, 

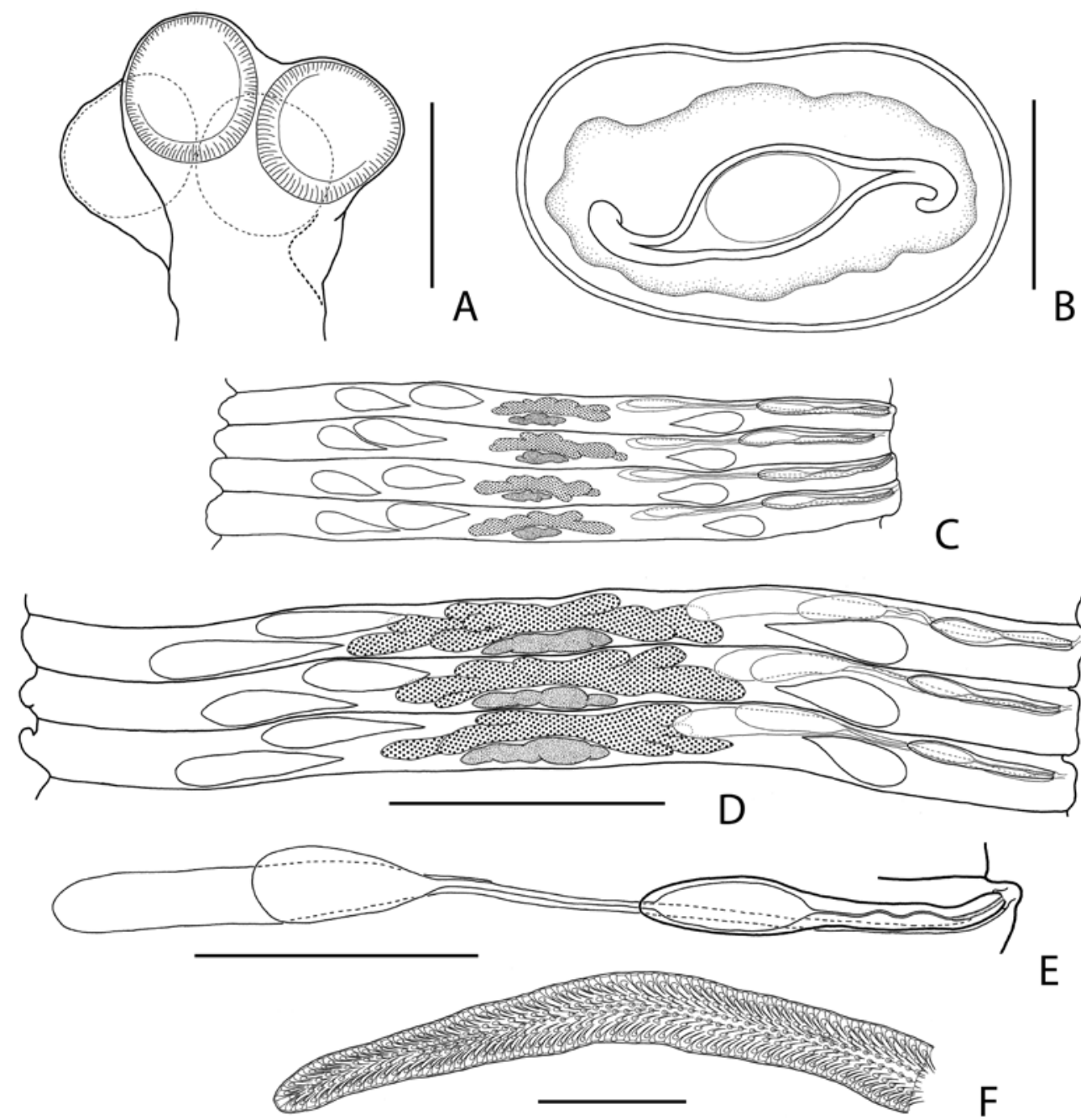

Fig. 1. Arostrilepis horrida (Linstow, 1901) (syntype). A-scolex; B - egg; C - male mature proglottides; D - hermaphroditic mature proglottides; $\mathbf{E}$ - genital ducts; $\mathbf{F}$ - cirrus. Scale bars: A, E = $200 \mu \mathrm{m} ; \mathrm{C}, \mathrm{D}=500 \mu \mathrm{m} ; \mathrm{B}, \mathrm{F}=20 \mu \mathrm{m}$.

usually three in number, of almost equal size, 220-290 $\times$ 50-70, pear-shaped, situated in triangle; poral testis separated from two antiporal testes by female genital glands. Cirrus-sac relatively short, $240-270 \times 30-40$, with welldeveloped external muscle layers, its antiporal end typically not reaching poral testis (Fig. 1E). Genital atrium simple, cup-shaped, deep, opens in anterior half of lateral proglottis margin. No evaginated cirrus in material studied. Invaginated cirrus $88-94 \times 6-10$, armed along its entire length with relatively large rosethorn-shaped spines (up to 4.5 long) (Fig. 1F). Internal seminal vesicle ovoid, $100-120 \times 30-34$, shorter than half of cirrus-sac length. External seminal vesicle elongate, $130-170 \times 40-50$, clearly outlined from vas deferens, distinctly smaller than seminal receptacle.

Ovary 620-690 wide, median, fan-shaped, irregularly lobed, ventral to testes, occupying substantial part of median field; overlapping testes (Fig. 1D). Vitellarium 35-44 $\times 240-270$, postovarian, median, scarcely lobed. Vagina tubular, clearly distinct from seminal receptacle; ventral to cirrus-sac. Seminal receptacle transversely elongate, 250-370 × 37-55.

Postmature, pregravid and gravid proglottides lacking in material studied. Single egg available among strobilar fragments. Egg $30 \times 53$, elliptic, with thin outer coat; oncosphere $10 \times 13$ (Fig. 1B). Embryophore fusiform, $40 \times$ 11 , with recurved (S-shaped) polar processes.

Type host: The brown rat Rattus norvegicus (Berkenhout), syn.: Mus decumanus Pallas.

Ty pe locality: Lower Saxony (Niedersachsen), Germany.

Type material: Syntype of Hymenolepis horrida (Linstow, 1901) (Taenia horrida Linstow, 1901), slide No. 3640$\mathrm{Q}$ from the Museum für Naturkunde, Berlin, Germany. The type material is represented by the single slide. The slide is in bad condition and contains only fragments of hymenolepidid specimens that are compressed, macerated, poorly stained 

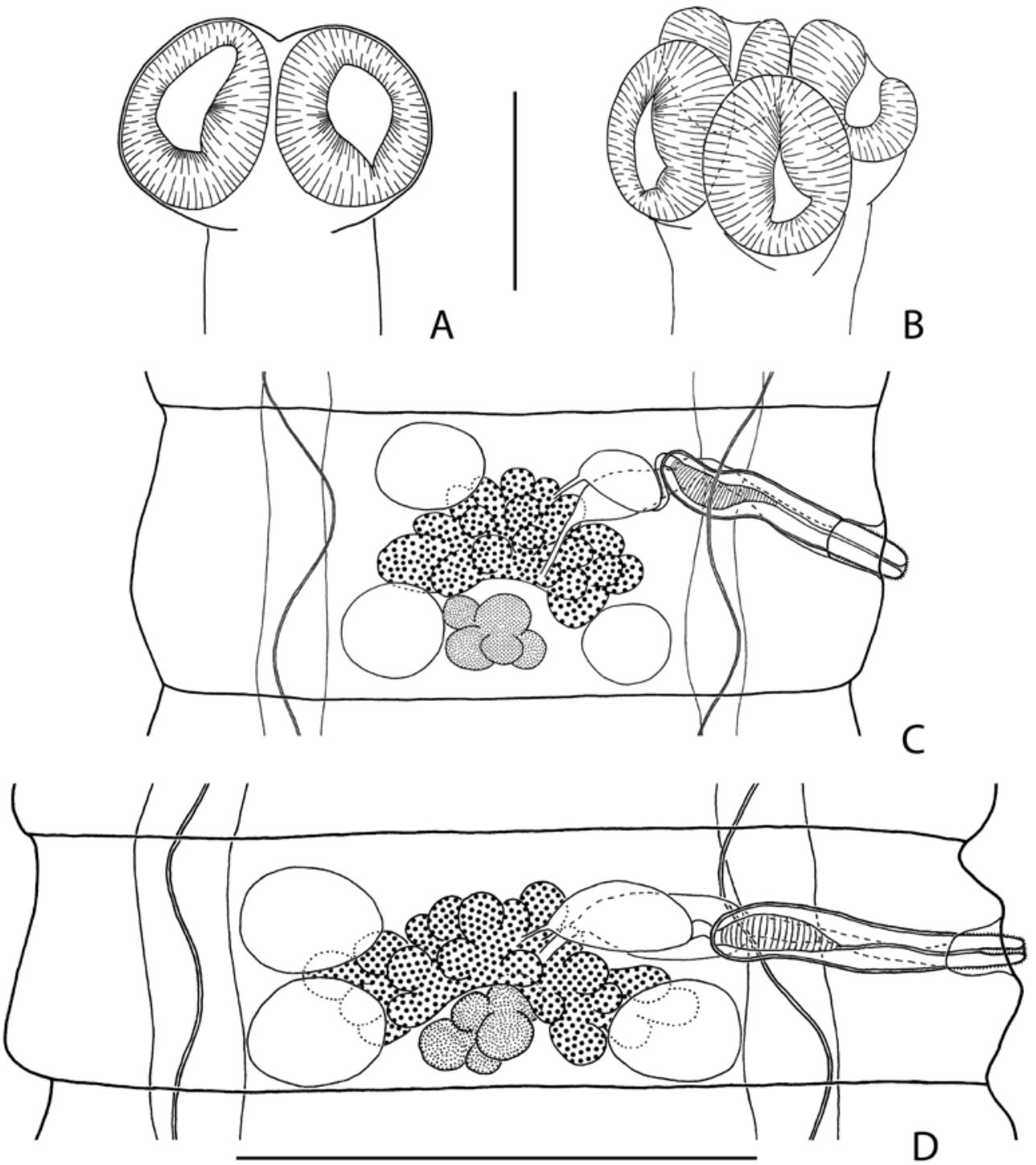

Fig. 2. Arostrilepis macrocirrosa sp. n. A, B - scolex; $\mathbf{C}$ - male mature proglottis; $\mathbf{D}$ - hermaphroditic mature proglottis. Scale bars: $\mathrm{A}, \mathrm{B}=200 \mu \mathrm{m} ; \mathrm{C}, \mathrm{D}=500 \mu \mathrm{m}$.

(probably with carmine) and with damaged tegument. In addition, a tube with dry cestode fragments is available (No. 4421-E), which is not informative for re-examination purposes.

Remarks. Despite the fact that the original description of $A$. horrida is incomplete and the type material is inadequate as a result of its poor condition, the available specimens remain recognisable and distinct. Further, we do not consider $A$. horrida as species inquirenda in order to preserve the nomenclatural stability of this group.

Mas-Coma and Tenora (1997) designated A. horrida (s. 1.) as the type species of the genus Arostrilepis but consistent with Johri (1956) suggested that it represented a constituent of a larger poorly differentiated complex of hymenolepidid cestodes across the Holarctic. Confusion over the identity of $A$. horrida has been exemplified by assumptions about considerable morphological variation and by numerous and widespread records for this species among microtine rodents (e.g., Schiller 1952). For example in their paper, Mas-Coma and Tenora (1997) presented drawings of a hymenolepidid cestode from Microtus subterraneus (Microtinae) from Hungary, which had been identified as $A$. horrida. They did not, however, describe these specimens, nor make direct comparisons with the type series for $A$. horrida. Based on comparisons to the type material in the present study, A. horrida sensu MasComa et Tenora, 1997 clearly differs in the width of the strobila (twice narrower than that of the type specimens) and in having a twice smaller cirrus, cirrus-sac and ovary than those of the type specimens (Table 1). We suggest that the type materials of $A$. horrida and A. horrida sensu Mas-Coma et Tenora, 1997 belong to different species 

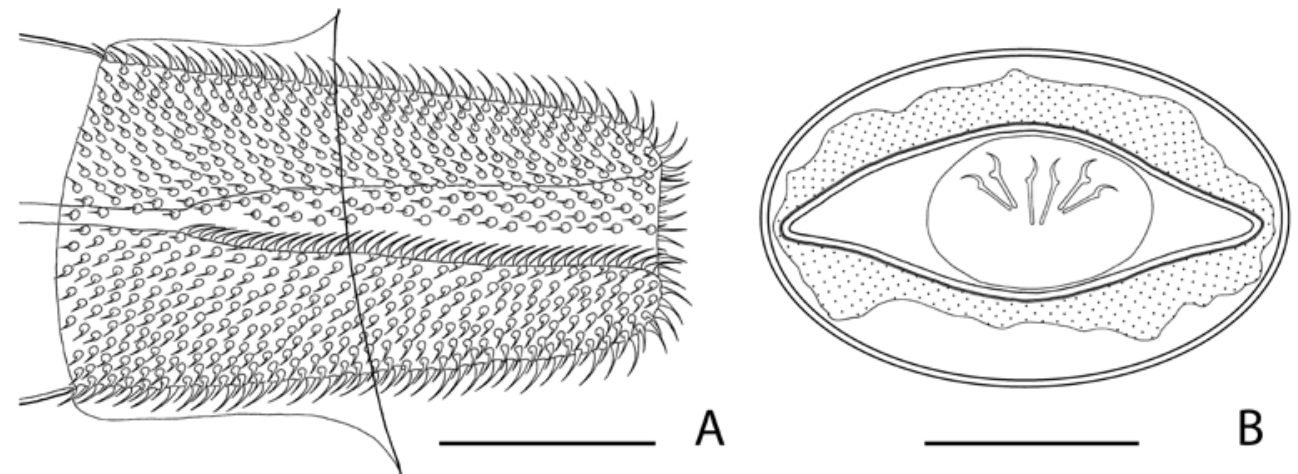

A

B
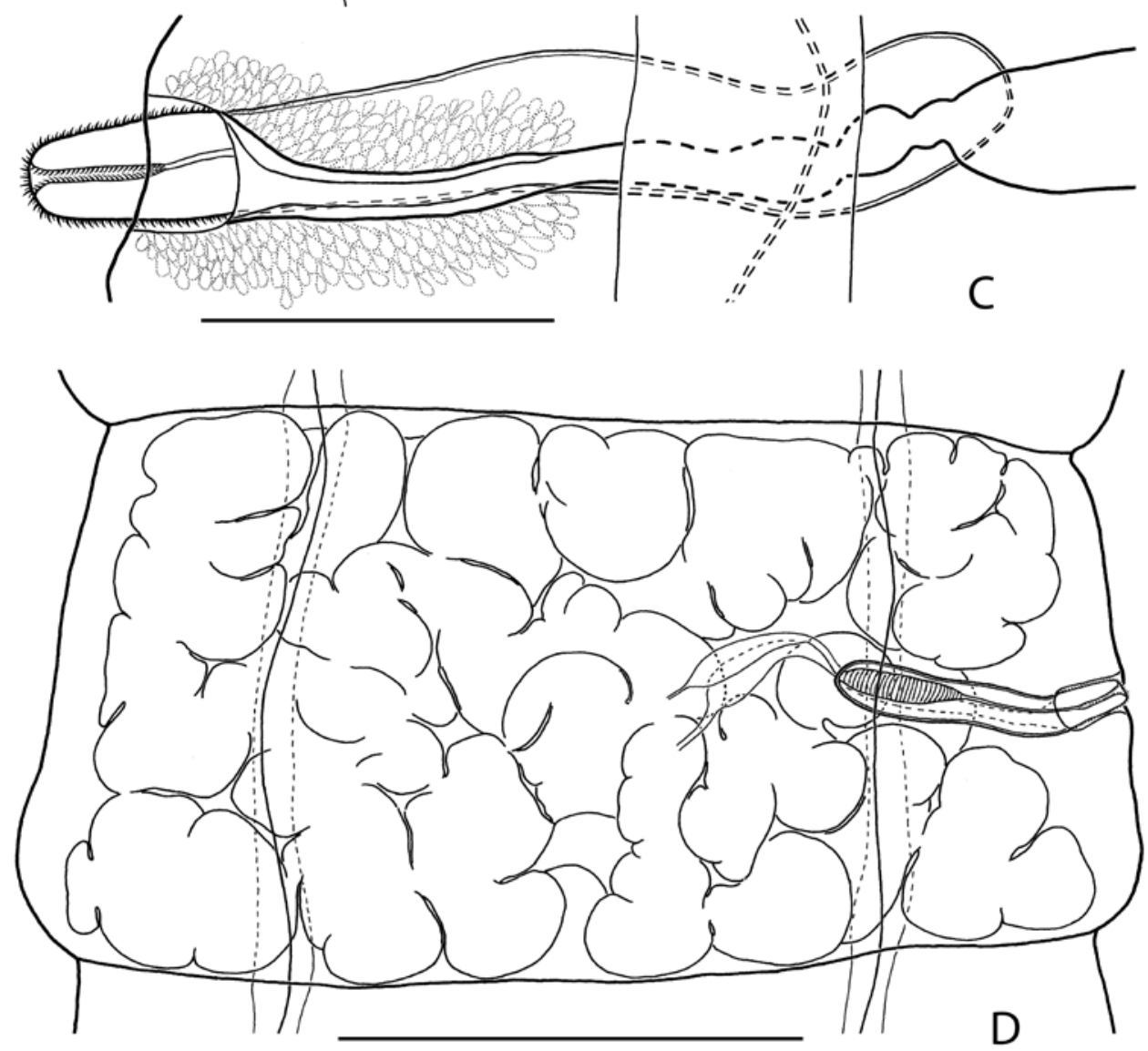

Fig. 3. Arostrilepis macrocirrosa sp. n. A - cirrus; B - egg; C - copulatory part of the vagina; $\mathbf{D}$ - gravid proglottis. Scale bars: $\mathrm{A}=20 \mu \mathrm{m} ; \mathrm{B}=25 \mu \mathrm{m} ; \mathrm{C}=100 \mu \mathrm{m} ; \mathrm{D}=500 \mu \mathrm{m}$.

of the same genus and highlights what may be a general problem for taxonomy and recognition of species limits in the genus.

\section{Arostrilepis macrocirrosa sp. n.}

Figs. 2, 3

Description (based on 12 specimens). Fully developed strobila 129 (116-170) mm long, with maximum width at pregravid or gravid proglottides, 1.0-1.10 (0.901.60) $\mathrm{mm}$. Strobila flat, consisting of 610-900 craspedote proglottides. Scolex slightly compressed dorso-ventrally, 300 (290-320) wide, clearly wider than neck. Suckers un- armed, ovoid in surface view, $180 \times 160(160-200 \times 140$ 170), prominent, with thick walls (Fig. 2A, B). Rhynchus and rostellar apparatus absent. Neck relatively long and narrow, 170 (150-190) wide.

Two pairs of osmoregulatory canals, without transverse anastomoses. Dorsal osmoregulatory canals thin, 2-3 $(2-4)$ wide, situated predominantly in same sagittal plane as ventral canals. Ventral osmoregulatory canals 60-90 (50-130) wide. Position of dorsal osmoregulatory canals not always constant; their loops may be situated laterally to ventral canals. Genital pores unilateral, dextral. Genital ducts may pass dorsally or between longitudinal osmo- 
regulatory canals within same strobila; intersegmental variation does not show any regularity (Fig. 2C, D). Development of proglottides gradual, protandrous. Strobilar part containing juvenile proglottides without external segmentation; proglottides become externally distinct at level of premature part of strobila.

Mature proglottides 220-250 × 800-830 (190-250 × 780-1160), transversely elongate, trapeziform (Fig. 2C, D). Testes relatively large, usually three in number, almost of equal size, $120-130 \times 90-100(110-170 \times 80-130)$, round or oval, situated in triangle; poral testis separated from two antiporal testes by female gonads. Arrangement of testes may vary. Cirrus-sac relatively short, 205-214 $\times$ 42-45 (195-230 × 35-45), with well-developed external muscular layers, commonly overlapping ventral longitudinal canal (Fig. 2D). Genital atrium simple, cup-shaped, deep, opens laterally about middle of lateral proglottis margin. Cirrus large, $107-118 \times 28-32(100-128 \times 27-$ $34)$, conical, armed along its entire length with relatively large (up to 3.5-4 long) rosethorn-shaped spines (Fig. 3A). Internal seminal vesicle with circular musculature, ovoid, $80-100 \times 30-32(70-120 \times 30-38)$, shorter than half of cirrus-sac length (Fig. 2D). External seminal vesicle transversely elongate, $120-160 \times 65-75(120-190 \times$ $60-80)$, clearly outlined from vas deferens, with size approximately equal to that of seminal receptacle.

Ovary 250-330 (250-430) wide, median, fan-shaped, irregularly lobed, ventral to male genital organs, occupying substantial part of median field, overlapping testes (Fig. 2D). Vitellarium 75-83 × 120-140 (73-86 $\times$ 120-190), postovarian, median, scarcely lobed. Vagina tubular, clearly distinct from seminal receptacle; ventral to cirrus-sac. Copulatory part of vagina $120-140 \times 15-18$ $(100-140 \times 12-20)$, thick-walled, covered externally by dense layer of small intensely stained cells; proximal part of vagina infundibular (Fig. 3C). Conductive part of vagina 40-55 × 12-22 (40-75 × 10-30), thin-walled, vastly varying in diameter depending on degree of filling with sperm. Seminal receptacle relatively small, transversely elongate, $120-145 \times 55-63(120-190 \times 55-78)$.

Uterus appears as complex of fine-walled anastomosing tubes of varying length and diameter, positioned ventrally to other organs. With development of proglottides, tubular structures increase in width and uterus becomes labyrinthine. Testes remain in postmature and pregravid proglottides; cirrus-sac and vagina persist in gravid proglottides. Gravid proglottides increase in length and may become slightly wider than long, 500-550 × 900$1100(440-750 \times 700-1500)$. Fully developed uterus labyrinthine, occupying entire median field and extending bilaterally beyond longitudinal osmoregulatory canals (Fig. 3D). Uterus contains numerous (up to 700-1100) small eggs. Eggs 33-45 $\times 52-63$, elliptic, with thin outer coat (Fig. 3B); oncosphere 17-20 × 25-32. Embryophore fusiform, 20-24 × 40-45, with straight polar processes. Embryonic hooks small, 8-8.5 long.
Type host: Myodes rutilus (Pallas) (Rodentia: Cricetidae).

Other hosts: Myodes rufocanus (Sundevall); M. glareolus (Schreber); rarely Microtus maximowiczii Schrank and M. oeconomus Pallas.

Type locality: Poronayskiy Reserve, Sakhalin Island, Russia.

Other localities (from the collection of ISEZH): Yarkovskiy Rayon, Tyumenskaya Oblast'; Village of Ust'Urgul'ka, suburbs of the city of Novosibirsk, Novosibirskaya Oblast'; Artybash, Altay Mts.; Bauntovskiy Rayon, River Bol'shoy Amalot, Republic of Buryatia, Russia; Hantaiskoe Reservoir, River Turmakit, Taymiyr Peninsula; SredneKolymskiy Rayon, Verkhoyan'e, River Tuostakh, Yakutia; Nyukzha River, Dyeltulakskiy Rayon, Amurskaya Oblast'; River Amgun', Khabarovskiy Kray, Russia.

Site of infection: Intestine.

Type material: Holotype: ISEZH No. 18.28.3.6, ex M. rutilus, Poronayskiy Reserve, 30.07.2005. Paratypes: No. 18.28.3.1, ex M. rutilus, 25.07.2005; No. 18.28.3.2, ex M. rutilus, 27.07.2005; No. 18.28.3.3, ex M. rutilus, 30.07.2005; No. 18.28.3.7, ex M. rutilus, 31.07.2005; No. 18.28.3.8, ex M. rutilus, 31.07.2005; No. C-579, ex M. rutilus, 31.07.2005; INVE 74207, ex M. rutilus, 30.07.2005. All paratypes are from the Poronayskiy Reserve and are deposited in ISEZH except INVE 74207 deposited in MHNG and C-579 deposited in IPCAS.

Etymology: This species has been named in reference to the size of its cirrus, which is the largest one among those of its congeners.

Remarks. Arostrilepis macrocirrosa is distinguished from congeners based on exceptionally large conical cirrus armed with relatively large rosethorn-shaped spines. The cirrus-sac of $A$. macrocirrosa is shorter than that in the syntype material of $A$. horrida but larger than in $A$. beringiensis. The ovary is smaller relative to those in $A$. horrida and $A$. microtis (Table 2). Furthermore, this species is characterized by the arrangement of its testes in a triangle. In addition, the cirrus-sac overlaps the ventral longitudinal osmoregulatory canal, the gravid proglottides may become slightly wider than long (in complete strobila) and the polar processes of the embryophore are straight.

\section{Arostrilepis tenuicirrosa sp. n.}

Figs. 4, 5

Description (based on 10 specimens). Fully developed strobila 120 (120-200) mm long, with maximum width at pregravid or gravid proglottides, $1.7-1.85(1.7-2.3) \mathrm{mm}$. Strobila flat, consisting of 650-1100 craspedote proglottides. Scolex slightly compressed dorso-ventrally, 360 (280-360) wide, clearly wider than neck. Suckers unarmed, ovoid, $170 \times 130(150-180 \times 110-140)$, prominent, with thick walls (Fig. 4A, B). Rhynchus and rostellar apparatus absent. Neck relatively long and narrow, 210 (160-210) wide.

Two pairs of osmoregulatory canals, without transverse anastomoses. Ventral osmoregulatory canals 80-130 (50130). Dorsal osmoregulatory canals very thin, $2-4$ wide, 

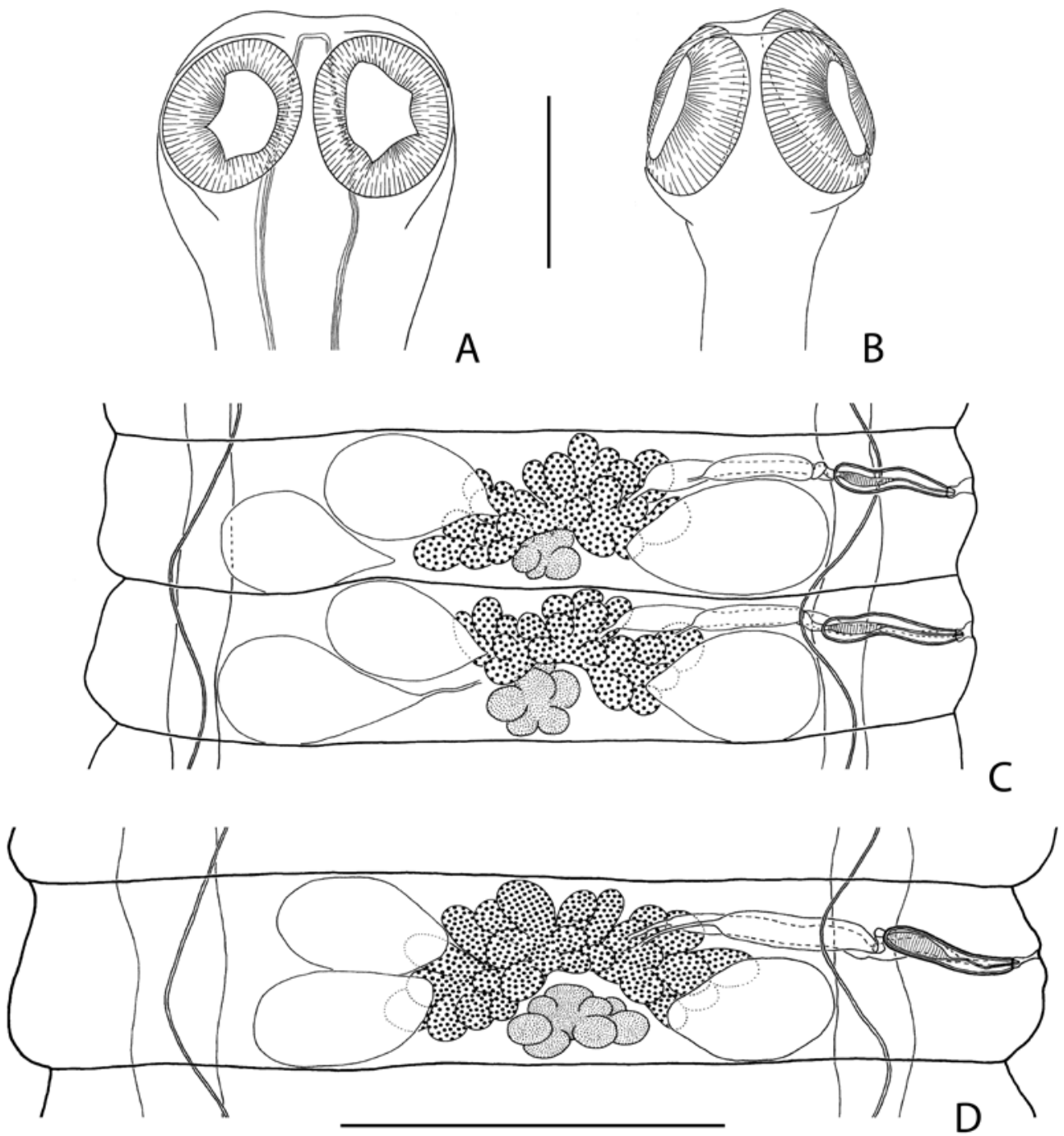

Fig. 4. Arostrilepis tenuicirrosa sp. n. A, B - scolex; C - male mature proglottides; D - hermaphroditic mature proglottis. Scale bars: A, $\mathrm{B}=200 \mu \mathrm{m} ; \mathrm{C}, \mathrm{D}=500 \mu \mathrm{m}$.

located mainly in same plane with ventral osmoregulatory canals. Position of dorsal osmoregulatory canals not constant, their loops may be situated laterally to ventral osmoregulatory canals. Genital pores unilateral, dextral. Genital ducts may pass dorsally or between longitudinal osmoregulatory canals within same individual; intersegmental variation does not show any regularity (Fig. 4C). Development of proglottides gradual, protandrous. Strobilar part containing juvenile proglottides without external segmentation; proglottides become externally distinct at level of premature part of strobila.

Mature proglottides 230-260 × 1200-1370 (210-270× 1200-1700), transversely elongate, trapeziform (Fig. 4C, D). Testes relatively large, usually three, almost of equal size, $210-230 \times 140-150(200-300 \times 140-170)$, pearshaped, usually situated in triangle; poral testis separated from two antiporal testes by female gonads. Arrangement of testes often not constant. Cirrus-sac relatively short,
175-200 × 35-39 $(175-225 \times 35-45)$, with well-developed external muscular layers. Antiporal part of cirrus-sac reaching ventral longitudinal canal, rarely overlapping or slightly crossing it (Fig. 4D). Genital atrium simple, infundibular, deep, opens at about middle of lateral proglottis margin. Cirrus 66-69 × 6-11 (64-71 × 5-12), with relatively wide conical basal region and narrow cylindrical distal region; armed along its entire length with 5-10 rows of small needle-shaped spines (up to 2-2.5 long) (Fig. 5A). Internal seminal vesicle with circular muscle, ovoid, 80-90 × 28-32 (75-95 × 28-35), shorter than half of cirrus-sac length (Fig. 4D). External seminal vesicle transversely elongated, 200-240 × 55-65 (170-240 × 40 68 ), clearly outlined from vas defferens, slightly smaller than seminal receptacle.

Ovary 400-430 (400-570) wide, median, fan-shaped, irregularly lobed, ventral to male genital organs, occupying substantial part of median field and overlapping testes 

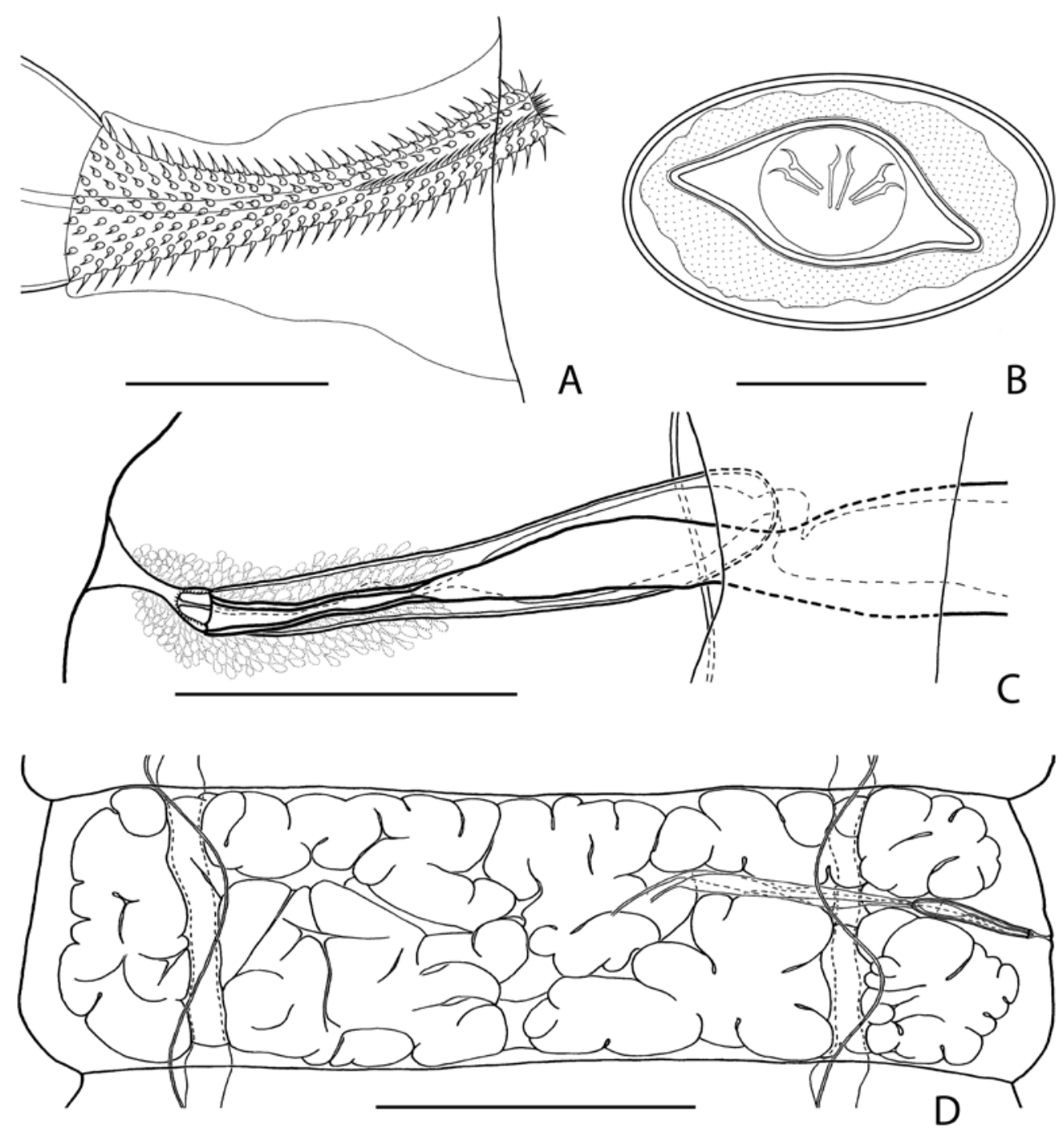

Fig. 5. Arostrilepis tenuicirrosa sp. n. A - cirrus; B - egg; C - copulatory part of the vagina; D - gravid proglottis. Scale bars: $\mathrm{A}=20 \mu \mathrm{m} ; \mathrm{B}=25 \mu \mathrm{m} ; \mathrm{C}=100 \mu \mathrm{m} ; \mathrm{D}=500 \mu \mathrm{m}$.

(Fig. 4D). Vitellarium 90-110 × 140-160 (80-110 × 140200), postovarian, median, scarcely lobed. Vagina tubular, clearly distinct from seminal receptacle; ventral to cirrussac. Copulatory part of vagina $74-80 \times 7-10(72-83 \times$ 6-10), thick-walled, covered externally by dense layer of small, intensely-stained cells, with infundibular proximal part (Fig. 5C). Conductive part of vagina $120-126 \times 25-$ $32(115-130 \times 22-34)$, thin-walled, varying in diameter depending on degree of filling with sperm. Seminal receptacle relatively small, transversely elongate, 175-185 $\times 35-43(175-290 \times 35-50)$.

Uterus appears as complex of fine-walled anastomosing tubes of various length and diameter; positioned ventrally to other organs. With development of proglottides, tubular structures increase in width and uterus becomes labyrinthine. Testes remain in postmature and pregravid proglottides; cirrus-sac and vagina persist in gravid proglotti- des. Gravid proglottides transversely elongate, 320-370 $\times 1500-1750(250-380 \times 1500-2000)$. Fully-developed uterus with labyrinthine aspect, occupying entire median field and extending bilaterally beyond longitudinal osmoregulatory canals (Fig. 5D). Uterus containing large number (up to 800-1000) of small eggs. Eggs 30-34 × 50-57, elliptic, with thin outer coats (Fig. 5B); oncosphere 14-17 $\times 18-22$. Embryophore fusiform, with straight polar processes, 18-22 × 35-44. Embryonic hooks small, 7-8 long.

Type host: Myodes rutilus (Pallas) (Rodentia: Cricetidae).

Other hosts: Myodes rufocanus (Sundevall); M. glareolus (Schreber); M. sikotanensis (Tokuda); rarely Microtus oeconomus Pallas.

Type locality: Poronayskiy Reserve, Sakhalin Island, Russia.

Other localities (from the collection of ISEZH): Yarkovskiy Rayon, Tyumenskaya Oblast'; suburbs of the city of 
Novosibirsk, Novosibirskaya Oblast'; Artybash, Altay Mts.; Bauntovskiy Rayon, River Bol'shoy Amalot, Baikal'skiy Reserve, Republic of Buryatia; suburbs of the town of Nosok, Taymir Peninsula; Gorniy Rayon, Sredne-Kolymskiy Rayon, Yakutia; River Nyukzha, Dyeltulakskiy Rayon, Amurskaya Oblast'; River Amgun', Khabarovskiy Kray; Lake Azabach'e, Kamchatka Peninsula; Kurilskiy Reserve, Kunashir Island, Russia.

Site of infection: Intestine.

Type material: Holotype: ISEZH No. 18.28.4.21, ex M. rutilus, Poronayskiy Reserve, 30.07.2005. Paratypes: No. 18.28.4.10, ex M. rutilus, 31.07.2005; No. 18.28.4.53, ex M. sikotanensis, 14.07.2006; No. 18.28.4.55, ex M. rufocanus, 14.07.2006; No. 18.28.4.56, ex M. rufocanus, 14.07.2006; No. C-578, ex M. sikotanensis, 16.07.2006; INVE 74210, ex M. sikotanensis, 16.07.2006. All paratypes are from the Kurilskiy Reserve except No. 18.28.4.10, which is from the Poronayskiy Reserve. All the type specimens are deposited in ISEZH except INVE 74210 in MHNG and C-578 deposited in IPCAS.

E ty mology: The name of this species refers to the shape of its cirrus, which has a narrow cylindrical distal region that is a unique character among its congeners.

Remarks. Arostrilepis tenuicirrosa is distinguished from A. macrocirrosa, A. horrida, A. microtis and $A$. beringiensis by the length and shape of the cirrus. In specimens of $A$. tenuicirrosa the cirrus is smaller relative to those in A. macrocirrosa, A. horrida and A. microtis, but longer in comparison to $A$. beringiensis. The cirrus is armed with relatively small needle-shaped spines and has a unique form, with a conical basal region and a very narrow cylindrical distal region; these features distinguish A. tenuicirrosa from all other Arostrilepis species. The cirrus-sac is shorter than in $A$. horrida, A. macrocirrosa and A. microtis but longer than in $A$. beringiensis. The ovary is smaller than in the syntype of $A$. horrida and in $A$. $m i$ crotis (see Table 2). The antiporal end of the cirrus-sac reaches the ventral longitudinal canal but rarely overlaps it. This species can be distinguished from $A$. beringiensis as its testes are arranged in a triangle; in the latter species, the testes form a flat angle or are situated in one row. Similarly, the testes form one row in A. microtis. Furthermore, the gravid proglottides are transversely elongate and the polar processes of the embryophore are straight in A. tenuicirrosa.

\section{Genetic distances between $A$. macrocirrosa and A. tenuicirrosa}

We obtained sequences for the ITS2 rRNA gene (587$630 \mathrm{bp}$ ) from multiple specimens of $A$. macrocirrosa and $A$. tenuicirrosa; sequence length did not show significant differences among specimens or species. Comparable data or specimens suitable for sequencing for other species of Arostrilepis were not available. A neighbour-joining (NJ) tree based on ITS2 sequences, rooted with two other hymenolepidids (Hymenolepis (s. 1.) nana and H. diminuta),

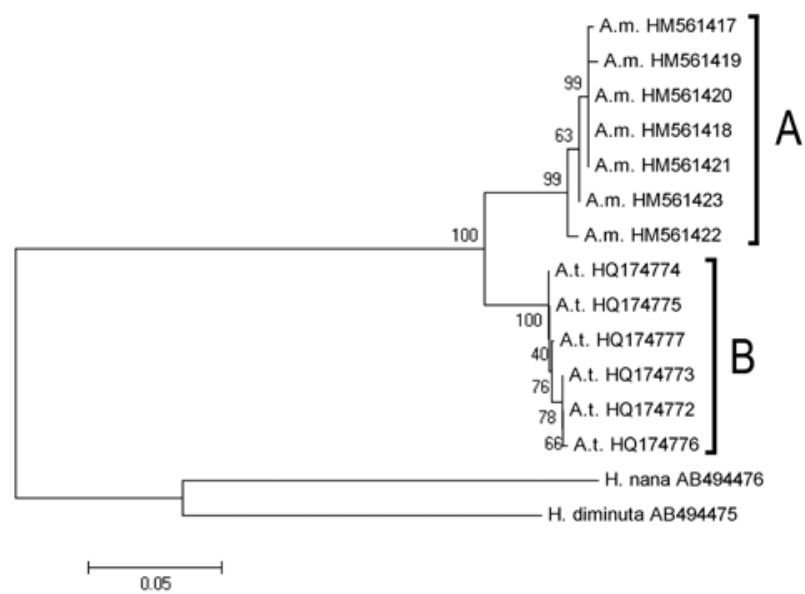

Fig. 6. Neighbour-joining tree of 13 ITS2 gene lineages of two Arostrilepis species; Hymenolepis diminuta and H. (s. 1.) nana are used as outgroup species. Numbers indicate bootstrap support based on 1,000 replicates. GenBank accession numbers of sequences are given after species names. Closely related lineages (intraspecific genetic distance of $\leq 1.4 \%$ ) which belong to A. macrocirrosa (A.m.) and A. tenuicirrosa (A.t.) are marked by bars $\mathrm{A}$ and $\mathrm{B}$, respectively.

was used to establish a phylogenetic diagnosis for $\mathrm{A}$. $\mathrm{mac}$ rocirrosa and $A$. tenuicirrosa. The taxonomically limited $\mathrm{NJ}$ analysis demonstrated reciprocal monophyly (100\% bootstrap) for lineages representing $A$. macrocirrosa and A. tenuicirrosa. Assessment of pairwise distances revealed significant genetic divergence (5.6-7.2\%) between lineages and specimens representing $A$. macrocirrosa (7 specimens, clade A) and A. tenuicirrosa (6 specimens, clade B) (Fig. 6). Intraspecific sequence diversity within A. macrocirrosa and A. tenuicirrosa was $<1.4 \%$ and $<$ $0.5 \%$, respectively. Genetic data corroborate the clear morphological differences that distinguish $A$. macrocirrosa and $A$. tenuicirrosa.

\section{Arostrilepis Mas-Coma et Tenora, 1997}

Emended generic diagnosis (after Mas-Coma and Tenora 1997, with modifications): Hymenolepididae of medium size. Development of proglottides gradual. Proglottides numerous, transversely elongate, craspedote. Scolex unarmed, without vestigial rostellar apparatus. Suckers unarmed, prominent. Dorsal and ventral osmoregulatory canals located on same sagittal plane. Ventral canals without transverse anastomoses. Genital pores unilateral, dextral. Genital ducts may pass either dorsally or between osmoregulatory canals within same strobila. Three testes situated in triangle or in one row; poral testis separated from two antiporal testes by female gonads. Cirrus-sac does not reach median line of proglottis. Cirrus armed. External and internal seminal vesicles present. Internal seminal vesicle with circular muscle. Ovary fan-shaped, median, lobed. Vitellarium postovarian, median, slightly 
Table 1. Comparison of measurements of Arostrilepis horrida from its original description and redescriptions (measurements in micrometres except where otherwise stated).

\begin{tabular}{llll}
\hline & Linstow 1901 & Present study & Mas-Coma and Tenora 1997* \\
\hline Strobila: length & $80 \mathrm{~mm}$ & - & - \\
Strobila: width & $2,14 \mathrm{~mm}$ & $1.87-1.93 \mathrm{~mm}$ & $0.84-1.01 \mathrm{~mm}$ \\
Scolex: width & 250 & $270-300$ & $183-229$ \\
Suckers: size & 120 & $133-145 \times 128-134$ & $125-158 \times 80-125$ \\
Hermaphroditic mature proglottis: & $180 \times 1540$ (middle part of strobila) & $90-130 \times 1840-1930$ & $108-124 \times 560-735$ \\
Testes: size & $88 \times 160$ & $50-70 \times 220-290$ & $45-62 \times 85-104$ \\
Cirrus-sac: size & 240 & $240-270 \times 30-40$ & $159 \times 35$ \\
Cirrus: size & $78 \times 10$ & $88-94 \times 6-10$ & 44 \\
Internal seminal vesicle: size & - & $100-120 \times 30-34$ & $64 \times 28$ \\
External seminal vesicle: size & $89 \times 35$ & $130-170 \times 40-50$ & $143 \times 32$ \\
Ovary: width & - & $620-690$ & $155-245$ \\
Vitellarium: size & - & $35-44 \times 240-270$ & $53-55 \times 95-110$ \\
Seminal receptacle: size & 440 & $250-370 \times 37-55$ & $133 \times 63$ \\
Gravid proglottis: size & $260 \times 2140$ (posterior part of strobila) & - & $225-438 \times 727-1010$ \\
Egg: size & $34 \times 68$ & $30 \times 53$ & $22-26 \times 47-50$ \\
Oncosphere: size & $10 \times 15$ & $10 \times 13$ & $10-11 \times 13-14$ \\
Embryophore: size & - & $11 \times 40$ & $11-12 \times 36-39$ \\
Embryonic hooks: size & 10 & - & 10 \\
\hline
\end{tabular}

*Measurements were taken from the illustrations in Mas-Coma and Tenora (1997).

Table 2. Main morphometric data distinguishing species of Arostrilepis (measurements in micrometres except where otherwise stated).

\begin{tabular}{|c|c|c|c|c|c|}
\hline & A. horrida ${ }^{1}$ & A. macrocirrosa sp. $\mathrm{n}$. & A. tenuicirrosa sp. n. & A. beringiensis ${ }^{1}$ & A. microtis $^{2}$ \\
\hline Strobila: width & $1.87-1.93 \mathrm{~mm}$ & $0.9-1.7 \mathrm{~mm}$ & $1.7-2.3 \mathrm{~mm}$ & $1.4-1.6 \mathrm{~mm}$ & $3.0-3.65 \mathrm{~mm}$ \\
\hline Suckers: size & $133-145 \times 128-134$ & $160-200 \times 140-170$ & $150-180 \times 110-140$ & $170-270 \times 120-160$ & $160-190 \times 120-150$ \\
\hline $\begin{array}{l}\text { Hermaphroditic mature } \\
\text { proglottis: size }\end{array}$ & $90-130 \times 1840-1930$ & $190-250 \times 780-1160$ & $210-270 \times 1200-1700$ & $200-280 \times 750-1200$ & $150-270 \times 1350-2000$ \\
\hline Testes: size & $220-290 \times 50-70$ & $110-170 \times 80-130$ & $200-300 \times 140-170$ & $100-185 \times 80-142$ & $160-190 \times 180-220$ \\
\hline Cirrus-sac: size & $240-270 \times 30-40$ & $195-230 \times 35-45$ & $175-225 \times 35-45$ & $95-140 \times 25-36$ & $220-250 \times 45-55$ \\
\hline Cirrus: size & $88-94 \times 6-10$ & $100-128 \times 27-34$ & $64-71 \times 5-12$ & $33-44 \times 10-12$ & $75-85 \times 20-22$ \\
\hline Spines: size & up to 4.5 & $3.5-4$ & $2-2.5$ & $2.2-2.7$ & $3-4$ \\
\hline Ovary: width & $620-690$ & $250-430$ & $400-570$ & $280-380$ & $450-620$ \\
\hline Vitellarium: size & $35-44 \times 240-270$ & $73-86 \times 120-190$ & $80-110 \times 140-200$ & $60-100 \times 130-180$ & $80-110 \times 160-230$ \\
\hline Copulative part of vagina: size & - & $100-140 \times 12-20$ & $72-83 \times 6-10$ & $55-84 \times 7-22$ & $100-110$ \\
\hline Seminal receptacle: size & $250-370 \times 37-55$ & $120-190 \times 55-78$ & $175-290 \times 35-50$ & $100-180 \times 30-40$ & $550-840 \times 60-85$ \\
\hline Gravid proglottis: size & - & $440-750 \times 700-1500$ & $250-380 \times 1500-2000$ & $300-430 \times 1250-1600$ & $310-370 \times 2000-3600$ \\
\hline Egg: size & $30 \times 53$ & $33-45 \times 52-63$ & $30-34 \times 50-57$ & $30-36 \times 48-56$ & $22-25 \times 45-48$ \\
\hline Oncosphere: size & $10 \times 13$ & $17-20 \times 25-32$ & $14-17 \times 18-22$ & $8-10 \times 13-15$ & $7.5-8.5 \times 14-15$ \\
\hline Embryophore: size & $11 \times 40$ & $20-24 \times 40-45$ & $18-22 \times 35-44$ & $10-14 \times 31-36$ & - \\
\hline
\end{tabular}

${ }^{1}$ Measurements were taken in present study; ${ }^{2}$ measurements from Gulyaev and Chechulin (1997).

Table 3. Cestode specimens included in the present analysis of ITS2 sequences.

\begin{tabular}{lllcl}
\hline Cestode species & Host species & Region, locality & $\begin{array}{l}\text { Total align- } \\
\text { ment (bp) }\end{array}$ & $\begin{array}{l}\text { GenBank } \\
\text { Acc. No. }\end{array}$ \\
\hline Arostrilepis macrocirrosa sp. n. & Myodes glareolus & Tyumenskaya Oblast' & 586 & HM561417 \\
A. macrocirrosa & M. glareolus & Tyumenskaya Oblast' & 597 & HM561418 \\
A. macrocirrosa & M. glareolus & Tyumenskaya Oblast' & 587 & HM561419 \\
A. macrocirrosa & M. glareolus & Tyumenskaya Oblast' & 591 & HM561420 \\
A. macrocirrosa & M. glareolus & Tyumenskaya Oblast' & 617 & HM561421 \\
A. macrocirrosa & Myodes rutilus & Sakhalin Island & 597 & HM561422 \\
A. macrocirrosa & M. rutilus & Sakhalin Island & 618 & HM561423 \\
Arostrilepis tenuicirrosa sp. n. & M. glareolus & Tyumenskaya Oblast' & 588 & HQ174772 \\
A. tenuicirrosa & M. glareolus & Tyumenskaya Oblast' & 603 & HQ174773 \\
A. tenuicirrosa & Myodes sikotanensis & Kunashir Island & 623 & HQ174774 \\
A. tenuicirrosa & M. sikotanensis & Kunashir Island & 630 & HQ174775 \\
A. tenuicirrosa & M. glareolus & Tyumenskaya Oblast' & 608 & HQ174776 \\
A. tenuicirrosa & Myodes rufocanus & Kunashir Island & 601 & HQ174777 \\
Hymenolepis diminuta & Rattus norvegicus & Japan: Hokkaido & 724 & AB494475 \\
Hymenolepis (s. l.) nana & Mus musculus & Japan: Tokyo & 702 & AB494476 \\
\hline
\end{tabular}


lobed. Fully developed uterus has labyrinthine aspect, extending bilaterally beyond longitudinal osmoregulatory canals. Eggs numerous, with thin outer coat. Embryophore fusiform, with polar processes. Parasites of cricetid (Cricetidae) and sciurid (Sciuridae) rodents in the Holarctic. Type species: A. horrida (Linstow, 1901).

Remarks. The generic name Arostrilepis was initially proposed by Mas-Coma (1982) but without sufficient data to be considered available in the terms of the International Code of Zoological Nomenclature. Subsequently, the genus Arostrilepis was erected properly (Mas-Coma and Tenora 1997) and A. horrida (s. 1.) was designated its type species on the basis of a description of specimens from the European pine vole (Microtus subterraneus SélysLongchamps) collected in Hungary. Establishing limits for diversity within Arostrilepis has been complicated.

Several incompletely described species have been reduced to synonymy under $A$. horrida. Baer (1932) considered Hymenolepis procera Janicki, 1904 and H. arvicolina Cholodkowsky, 1913 both from voles as synonyms of $A$. horrida. Spassky (1954) recognised voles (Microtinae) as the main definitive hosts of $H$. horrida and added H. sciurina Cholodkowsky, 1913 from squirrels (Sciuridae) to its synonyms on the basis of the similarity of their egg morphology (embryophore with pointed ends) and the presence of armed cirrus. Later, $H$. mathevossianae Akhumian, 1946 from the Turkish hamster, Mesocricetus brandti (Nehring) from Armenia was also placed among the synonyms of $H$. horrida (see Rybicka 1959). However, $H$. arvicolina has characteristics of the genus $H y$ menolepis (s. str.) (for the current generic definition, see Czaplinski and Vaucher 1994) as its scolex has a rostellar pouch, its suckers do not exceed the margins of the scolex and its testes are situated in one row. In the description of $H$. sciurina, the only measurements presented are those of the total length, the width of the strobila and the size of the ovary; the illustrations are schematic (Cholodkowsky 1913). Therefore, the description is inadequate and does not allow comparisons with the species of the genus Arostrilepis. Although the type series of $H$. arvicolina and $H$. sciurina are mentioned in the collection catalogue of the Zoological Institute of the Russian Academy of Sciences (St. Petersburg), they are not currently registered and are considered lost. For this reason, we regard them as species inquirendae.

Hymenolepis procera can be distinguished from A. horrida and from other species of Arostrilepis by its very short strobila $(28-40 \mathrm{~mm})$, the arrangement of its testes in one row and its significantly smaller cirrus-sac size (130) (see Table 2). Hymenolepis mathevossianae differs from the species of the genus Arostrilepis by its cup-shaped suckers, the arrangement of the testes in one row, its very small cirrus-sac $(80 \times 50)$ and the occurrence in hamsters. The affiliation of this species to the genus Arostrilepis is not obvious as it has saccate uterus and its eggs have never been described. Unfortunately, the type series of these species are also lost and the original descriptions are poor. For this reason, we consider them as species inquirendae.

Therefore, the validity and the generic allocation of $H$. procera, $H$. arvicolina, $H$. sciurina and $H$. mathevossianae require further study. However, we cannot accept their placement as synonyms of $A$. horrida as this generic affiliation has not been based on reliable morphological comparisons. Furthermore, it affects both generic concept of Arostrilepis and host range of its type species.

Mas-Coma and Tenora (1997) placed A. neurotrichi (Rausch, 1962) from North-American moles in the genus Arostrilepis. Earlier, Mas-Coma (1982) had chosen this cestode as a type species of the invalid genus Corderolepis Mas-Coma, 1982, which we consider as nomen nudum. Due to its tubular seminal receptacle, testes not separated by female genital glands and uterus situated in median field of proglottis, this hymenolepidid species appreciably differs from any species of Arostrilepis, and as such it is excluded from the genus.

\section{DISCUSSION}

The long list of definitive hosts of Arostrilepis horrida is a consequence of incorrect identifications (see above). The original description of Taenia horrida, which was illustrated with a cross-sectioned mature proglottis (Linstow 1901), was not a reliable basis for subsequent comparisons. This resulted in a series of erroneous identifications and various hymenolepidid cestodes from rodents without rostellar apparatus were reported as $A$. horrida. Among others, $A$. horrida sensu Mas-Coma and Tenora, 1997 from Microtus subterraneus, which has been used as a basis for the original generic diagnosis of Arostrilepis (see Mas-Coma and Tenora 1997), is not conspecific with the type series of $A$. horrida. In the extensive collections of hymenolepidids from rodents from the Asian part of Russia, deposited at ISEZH, we did not find cestodes with morphology corresponding to the type series of $A$. horrida. Therefore, the only reliable record of the host and geographical range of the type species of Arostrilepis is that contained within its original description (Linstow 1901). In addition, as discussed above, Hymenolepis neurotrichi from Nearctic moles, does not belong to the genus Arostrilepis, contrary to the opinion of Mas-Coma and Tenora (1997).

As revealed by the present study, the main differentiating characters for species of Arostrilepis are the form and size of the cirrus. The other characters may vary and overlap substantially among the species within the genus. Furthermore, variations in some morphometrical characters are due to the compression and (or) maceration of specimens. For this reason, we do not compare the two new species described here with the incomplete descriptions of $A$. horrida (s. 1.) by other authors (Schiller 1952, Voge 1952, Żarnowski 1955, Rybicka 1959, Murai and Tenora 1973, Egorova and Nadtochii 1975, Mas-Coma 
and Tenora 1997, Asakawa et al. 2002), which were based on specimens from various hosts and regions. Their identifications require additional studies. Special emphasis should be placed on integrated methods using molecular and morphological criteria and evaluation of the structural characters which have been shown to be reliable in the course of the present study.

There are further questions related to the morphology of the type species $A$. horrida. Unfortunately, the type series re-examined in the current study does not contain pregravid and gravid proglottides. In addition, the identification of the type host remains doubtful. As mentioned above, A. horrida had not been recorded in Rattus norvegicus after the original description. Therefore, it is possible that this is either associated with a record of accidental parasitism or the original description contains an erroneous host identification.

In summary, there are five species in the genus Arostrilepis now recognised from the Palaearctic Region: $A$. horrida, A. beringiensis, A. microtis, A. macrocirrosa, and $A$. tenuicirrosa. These species can be clearly distinguished by the shape and size of the cirrus, the position of the testes and host specificity. New distinctive generic-level characters for Arostrilepis have been detected: i.e., the irregular position of the genital ducts relative to the longitudinal osmoregulatory canals within the same strobila and the presence of circular musculature in the wall of the internal seminal vesicle. The level of intraspecific divergence among ITS2 sequences in $A$. macrocirrosa attains $1.4 \%$, which may be high for this DNA region. Unfortunately, no comparable data on the intraspecific differences in the ITS2 sequences of other hymenolepidid tapeworms exist. Previously, it was shown that ITS2 sequence similarity may vary within a single species, e.g., 93.8-99.1\% in Bothriocephalus acheilognathi Yamaguti, 1934 (see Bean et al. 2007). In Diphyllobothrium dendriticum (Nitzsch, 1824 ) and $D$. ditremum (Creplin, 1825), the variation is 97.0-98.0\% and 98.2-99.9\%, respectively (Škeříková et al. 2006). These values correspond to the variation recorded within a single species in the present study. Our data confirm the interspecific differences and reciprocal monophyly between $A$. macrocirrosa and A. tenuicirrosa and demonstrate that additional molecular studies will be useful for improving the taxonomy of Arostrilepis.

It should be noted that cestodes of the genus Arostrilepis from both sides of Beringia were studied based on morphological and molecular methods (Hoberg et al. 2003, Cook et al. 2005). Across the amphiberingian region, 10 distinct genetic lineages of Arostrilepis were recognised among various genera of the Microtinae that may deserve to be considered as distinct species (including five lineages from Myodes). These observations support the growing recognition of $A$. horrida as a widespread complex of cryptic species (e.g., Hoberg, et al. 2003, Cook et al. 2005). Within this complex, the resolution of identity of $A$. horrida (s. 1.) relative to a diverse assemblage of congeners depends in part on new collections from the type locality. Descriptions of two new species of Arostrilepis from Myodes spp. from the Eastern Palaearctic serve in part to corroborate a geographically complex assemblage of tapeworms among microtine hosts.

Acknowledgements. We are grateful to Konstantin Feodorov, Nikolai Dokuchaev, Aleksandr Chechulin, Sergey Karpenko and Marina Malkova for making cestode specimens from rodents from Western and Eastern Siberia, North-Eastern Altai and the Russian Far East available for this study. Dr. Eric P. Hoberg kindly discussed results of ongoing work on microtine tapeworm faunas under the Beringian Coevolution Project and provided some editorial assistance on this paper. We wish to thank the curators of the cestode collections, Dr. Birger Neuhaus (Museum für Naturkunde, Berlin), Dr. Larisa Filimonova (Centre of Parasitology, A.N. Severtsov Institute of Ecology and Evolution, RAS, Moscow) and Dr. Eric P. Hoberg and Ms. Patricia Pilitt (US National Parasite Collection, ARS, USDA, Beltsville) for loaning type materials. We also thank the staff of the Poronayskiy Reserve and the Kurilskiy Reserve, who kindly helped in collecting of materials. A substantial portion of the work was funded by the Russian Fund of Fundamental Research (grants 05-04-49010, 08-04-00342 and 06-04-63137). Postdoctoral fellowship of A.A. Makarikov is being funded by European Union Structural Funds project "Postdoctoral Fellowship Implementation in Lithuania" within the framework of the Measure for Enhancing Mobility of Scholars and Other Researchers and the Promotion of Student Research (VP1-3.1-ŠMM-01) of the Program of Human Resources Development Action Plan.

\section{REFERENCES}

Asakawa M., Tenora F., Koubková B. 2002: Arostrilepis horrida (Linstow, 1901) (Cestoda: Hymenolepididae) from Eothenomys spp. (Rodentia) in Japan. Biogeography 4: 51-55.

BAER J.G. 1932: Contribution á la faune helminthologique de Suisse. Rev. Suisse Zool. 39: 1-57.

Bean M.G., ŠKeříková A., Bonner T.H., Scholz T., Huffman D.G. 2007: First record of Bothriocephalus acheilognathi in the Rio Grande with comparative analysis of ITS2 and V4-18S rRNA gene sequences. J. Aquat. Anim. Health 19: 71-76.

Cholodkowsky N. 1913: Cestodes nouveaux ou peu connus. Deuxieme serie. Annu. Mus. Zool. Acad. Impér. Sci. St. Pétersb. 18: 221-232.
Cook J.A., Hoberg E.P., Koehler A., Henttonen H., Wickström L., Haukisalmi V., Galbreath K., Chernyavski F., DokuChaev N., Lazuhtkin A., MacDonald S.O., Hope A., Waltari E., Runck A., Veitch A., Popko R., Jenkins E., Kutz S., ECKERLIN R. 2005: Beringia: intercontinental exchange and diversification of high latitude mammals and their parasites during Pliocene and Quaternary. Mammal Study 30: 33-44.

Czaplinski B., Vaucher C. 1994: Family Hymenolepididae Ariola, 1899. In: L.F. Khalil, A. Jones and R.A. Bray (Eds.), Keys to the Cestode Parasites of Vertebrates. CAB International, Wallingford, UK, pp. 595-663. 
EGoRova T.P., NADTochi E.V. 1975: [Helminthes of some rodents of the Kolyma Mountains.] In: Gel'mintologicheskie Issledovaniya Zhivotnykh i Rastenii. (Trudy Biologo-Pochvennogo Instituta AN SSSR). Vol. 26, pp. 33-44. (In Russian.)

Fedorov K.P. 1986: [Patterns of spatial distribution of parasitic worms.] Izdatel'stvo Nauka, Novosibirsk, 256 pp. (In Russian.)

Genov T. 1984: [Helminths of insectivores and rodents in Bulgaria.] Izdatelstvo na Bulgarskata akademiya na naukite, Sofia, 348 pp. (In Bulgarian.)

Gulyaev V.D., Chechulin A.I. 1997: Arostrilepis microtis n. sp. (Cyclophyllidea: Hymenolepididae), a new cestode species from Siberian rodents. Res. Rev. Parasitol. 57: 103-107.

HaLl T. 2005: BioEdit: Biological sequence alignment Editor written for Windows 95/98/2000/XP. http://www.mbio.ncsu. edu/BioEdit/bioedit.html.

Haukisalmi V., Hardman L.M., Hardman M., Laakkonen J., Niemimaa J., Henttonen H. 2007: Morphological and molecular characterization of Paranoplocephala buryatiensis n. sp. and P. longivaginata Chechulin \& Gulyaev, 1998 (Cestoda: Anoplocephalidae) in voles of the genus Clethrionomys. Syst. Parasitol. 66: $55-71$.

Hoberg E.P., Kutz S.J., Galbreath K.E., Cook J.A. 2003: Arctic biodiversity: from discovery to faunal baselines - revealing the history of a dynamic ecosystem. J. Parasitol. 89: 84-95.

JANICKI C. 1904: Zur Kenntnis einiger Säugetiercestoden. Zool. Anz. 27: 770-782.

JANICKI C. 1906: Studien an Säugetiercestoden. Z. Wiss. Zool. 81: 505-597.

Johri G.N. 1956: On a new cestode from the palm squirrel, Funambulus palmarum Linn. Proc. Natl. Acad. Sci. Allahabad, ser. B, 26: 274-277.

Kontrimavichus V.L., Smirnova L.V. 1991: [Hymenolepis beringiensis $\mathrm{sp}$. $\mathrm{n}$. from the Siberian lemming (Lemmus sibiricus Kerr) and the problem of the sibling species in helminthology.] In: Evoljucia parazitov (Materialy I Vsesojuznogo simpoziuma, Tol'jati, 1990), pp. 90-104. (In Russian.)

Kumar S., Tamura K., Nei M. 2004: MEGA3: Integrated software for molecular evolutionary genetics analysis and sequence alignment. Briefings Bioinformatics 5: 150-163.

Linstow O. 1901: Taenia horrida, Tetrabothrium macrocephalum und Heteraksis distans. Arch. Naturgesch. Berl. 67(1): 1-10.

Mas-Coma S. 1982: Helminthes de micromammiferes. Spécificité évolution et phylogénie des cestodes Arostrilepididae Mas-Coma et Tenora, 1981 (Cyclophyllidea: Hymenolepidoidea). Mém. Mus. Natl. Hist. Nat. 123: 185-194.

Mas-Coma S., Tenora F. 1997: Proposal of Arostrilepis n. gen. (Cestoda: Hymenolepidae). Res. Rev. Parasitol. 57: 93-101.

Mas-Coma S., Tenora F., Gallego J. 1980: Consideraciones sobre los Hymenolepídidos inermes de Roedores, con especial referencia a la problemática entorno a Hymenolepis diminuta. Circular Farmacéutica, Barcelona, 38 (267): 137-152.
Murai E., Tenora F. 1973: Hymenolepis horrida (Linstow, 1901) from Microtinae in Hungary. Parasitol. Hung. 6: 111-116.

Окамото M., Agatsuma T., Kurosawa T., Ito A. 1997. Phylogenetic relationships of three hymenolepidid species inferred from nuclear ribosomal and mitochondrial DNA sequences. Parasitology 115: 661-666.

Ryвicka K. 1959: Some remarks on the classification of the family Hymenolepididae Fuhrmann, 1907 (Cestoda). Acta Parasitol. Pol. 7: 499-520.

Ryzhikov K.M., Gvozdev E.V., Tokobaev M.M., Shaldybin L.S., Matzaberidze G.V., Merkusheva I.V., Nadtochil E.V., Khohlova I.G., Sharpilo L.D. 1978: [Keys to the helminths of the rodent fauna of the USSR. Cestodes and trematodes.] Izdatel'stvo Nauka, Moskva, 232 pp. (In Russian.)

Sambrook J., Russell D.W. 2002: Molecular cloning: a laboratory manual. 3rd ed. Cold Spring Harbor Laboratory Press, New York, USA.

Schiller E.L. 1952: Studies on the helminth fauna of Alaska. X. Morphological variation in Hymenolepis horrida (von Linstow, 1901) (Cestoda: Hymenolepididae). J. Parasitol. 38: 554-568.

ŠKeřííová A., Brabec J., Kuchta R., Jiménez J.A., García H.H., Scholz T. 2006: Is the human-infecting Diphyllobothrium pacificum a valid species or just a South American population of the Holarctic fish broad tapeworm, D. latum? Am. J. Trop. Med. Hyg. 75: 307-310.

ŠKeříkovÁ A., HYPŠA V., Scholz T. 2001: Phylogenetic analysis of European species of Proteocephalus (Cestoda: Proteocephalidea): compatibility of molecular and morphological data and parasite-host coevolution. Int. J. Parasitol. 31: 1121-1128.

Skrjabin K.I., Matevosyan E.M. 1948: [Hymenolepidids of mammals.] Trudy Gel'mintologicheskoy Laboratorii 1: 15-92. (In Russian.)

SPASSKY A.A. 1954: [Classification of hymenolepidids of mammals.] Trudy Gel'mintologicheskoy Laboratorii 7: 120-134. (In Russian.)

Surkov V.S., NAdtochi E.V. 1970: [Zoogeographical review of the helminth fauna of murid rodents of the south part of Sakhalin Island.] Izvestija Sakhalinskogo Otdela Geographicheskogo Obschestva SSSR 1: 229-235. (In Russian.)

Thompson J.D., Higgins D.G., Gibson T.J. 1994: CLUSTAL W: improving the sensitivity of progressive multiple sequence alignment through sequence weighting, position-specific gap penalties and weight matrix choice. Nucleic Acids Res. 22: 4673-4680.

Vainio E.J., Korhonen K., Hantula J. 1998: Genetic variation in Phlebiopsis gigantea as detected with random amplified microsatellite (RAMS) markers. Mycol. Res. 102: 187-192.

VoGE M. 1952: Variation in some unarmed Hymenolepididae (Cestoda) from rodents. Univ. Calif. Publ. Zool. 57: 1-52.

ŻARNOWSKI E. 1955: [Parasitic worms of forest small mammals (Rodentia and Insectivora) near Pulawy (Lublin). I. Cestoda.] Acta Parasitol. Pol. 3: 279-368. (In Polish.)

Accepted 6 October 2010 